\title{
Hesperidin Alleviates Cecal Ligation and Puncture-Induced Lung and Kidney Injuries
}

\section{Hesperidin, Çekal Ligasyonu ve Delinmeye Bağlı Akciğer ve Böbrek Yaralanmalarını Hafifletir}

Derya Güzel Erdoğan, Ayhan Tanyeli, Fazile Nur Ekinci Akdemir, Mustafa Can Güler, Ersen Eraslan, Selim Çomakl1, Elif Polat ${ }^{2}$

1 Sakarya University, Physiology, Sakarya, Turkey

2 Atatürk University, Physiology, Erzurum, Turkey

3 Ağrı İbrahim Çeçen University Nutrition and Dietetics, Ağrı, Turkey

4 Bozok University, Physiology, Yozgat, Turkey

5 Atatürk University, Pathology, Erzurum, Turkey

6 Atatürk University, Biochemistry, Erzurum, Turkey

Yazışma Adresi

Correspondence Address

\section{Fazile Nur EKİNCi AKDEMIR}

Ağrı İbrahim Çeçen University Nutrition and Dietetics, Ağr1, Turkey

fazilenur85@gmail.com

Geliş tarihi / Received : Ekim 12, 2020 Kabul tarihi / Accepted : Ocak 07, 2021 Elektronik yayın tarihi : Ocak 01, 2022 Online published

Bu makalede yapılacak atıf: Cite this article as:

Güzel Erdoğan D, Tanyeli A, Ekinci Akdemir F.N, Can Güler M, Eraslan E, Çomaklı S, Polat E.

Hesperidin Alleviates Cecal Ligation and Puncture-Induced Lung and Kidney Injuries. Akd Med J 2022; 8(1):1-8.

Derya Güzel Erdoğan

ORCID ID: 0000-0002-7618-5043

Ayhan Tanyeli

ORCID ID: 0000-0002-0095-0917

Fazile Nur Ekinci Akdemir

ORCID ID: 0000-0001-9585-3169

Mustafa Can Güler

ORCID ID: 0000-0001-8588-1035

Ersen Eraslan

ORCID ID: 0000-0003-2424-2269

Selim Çomaklı

ORCID ID: 0000-0002-8744-7686

Elif Polat

ORCID ID: 0000-0003-0042-4084

\section{ABSTRACT \\ Objective:}

The potential useful features of hesperidin (Hes) was examined against lung and kidney injuries triggered by cecal ligation and puncture (CLP) in rats in current study.

\section{Materials and Methods:}

32 Wistar Albino male rats were randomly allocated as sham, CLP, Hes $100 \mathrm{mg} / \mathrm{kg}$ and Hes 200 $\mathrm{mg} / \mathrm{kg}$ groups. For the CLP process under anesthesia, the abdominal area was shaved and cleaned. The cecum was tied with a 4.0 suture and pierced by 18 -gauge needle. Using this method, the experimental sepsis model was created. The lung and kidney tissues were removed at the end of the experiment. Biochemical and immunohistochemical analyzes were performed. Hes was administered by oral gavage at the doses of 100 and $200 \mathrm{mg} / \mathrm{kg}$ for 15 days.

\section{Results:}

Total oxidant status (TOS), malondialdehyde (MDA) and oxidative stress index (OSI) levels, myeloperoxidase (MPO) activity raised significantly while superoxide dismutase (SOD) and total antioxidant status (TAS) values declined in CLP group compared to sham group in lung and kidney tissues. On the contrary, SOD and TAS levels increased while MPO activity, TOS, OSI and MDA levels decreased due to Hes treatments. Caspase-3 and LC3B immunopositivity raised significantly in CLP group compared to sham group in lung and kidney tissues while decreased was observed in Hes treatment groups.

\section{Conclusion:}

In this study, in the light of our biochemical and immunohistochemical results we conclude that, Hes demonstrated an effective protection against CLP-induced lung and kidney tissue injuries in rats.

Key Words: Sepsis, Hesperidin, Lung, Kidney, Oxidative stress, Autophagy

ÖZ

Amaç:

Bu çalışmada, sıçanlarda çekal ligasyon ve delme (CLP) ile tetiklenen akciğer ve böbrek hasarlarına karşı hesperidinin (Hes) potansiyel yararlı özellikleri incelenmiştir.

\section{Gereç ve Yöntemler:}

32 adet Wistar Albino erkek rat rastgele olarak sham, CLP, Hes 100 mg/kg ve Hes 200 mg/kg 
Güzel Erdoğan D.et al

gruplarına ayrıldı. Anestezi altında CLP işlemi için karın bölgesi tıraş edilerek temizlendi. Çekum 4,0 sütür ile bağlandı ve 18' lik iğne ile delindi. Bu metod kullanılarak deneysel sepsis modeli oluşturuldu. Deneyin sonunda akciğer ve böbrek dokuları çıkarıldı. Biyokimyasal ve immünohistokimyasal analizler yapıldı. Hes, 15 gün süreyle 100 ve 200 $\mathrm{mg} / \mathrm{kg}$ dozlarında oral gavaj ile uyguland.

\section{Bulgular:}

Sham grubu CLP grubu ile kıyaslandığında akciğer ve böbrek dokularında Total oksidan durum (TOS), malondialdehit (MDA) ve oksidatif stres indeksi (OSI) düzeyleri, miyeloperoksidaz (MPO) aktivitesi anlamlı olarak artarken süperoksit dismutaz (SOD) ve total antioksidan durum (TAS) değerleri azaldı. Bunun aksine, Hes tedavilerine bağlı olarak SOD ve TAS seviyeleri artarken MPO aktivitesi, TOS, OSI ve MDA seviyeleri azalmıştır. Sham grubu CLP grubu ile kıyaslandığında akciğer ve böbrek dokularında Kaspaz-3 ve LC3B immünopozitifliği anlamlı olarak artarken, Hes tedavi gruplarında azalma gözlendi.

\section{Sonuç:}

$\mathrm{Bu}$ çalışmada, sunduğumuz biyokimyasal ve immünohistokimyasal bulgularımız ışığında, Hes' in sıçanlarda CLP' ye bağlı akciğer ve böbrek dokusu hasarlarına karşı etkili bir koruma sağladığı belirlenmiştir.

Anahtar Sözcükler: Sepsis, Hesperidin, Akciğer, Böbrek, Oksidatif stres, Otofaji

\section{INTRODUGTION}

Sepsis is a complicated syndrome that occurs in case of systemic inflammatory response syndrome (SIRS). SIRS results from infection which is mediated by endogenous mediators affecting all organs and systems (1). Sepsis leads to respiratory, renal, hepatic, cardiovascular and endocrine organ dysfunctions as a result of many changes such as increased microvascular permeability, acute lung injury, coagulation abnormalities, hypovolemia, decreased myocardial contractility, hypoxia, decreased systemic vascular resistance and hyperglycemia (2). Lungs are believed to be the first and mostly affected organ due to intraabdominal sepsis (3). SIRS can develop for many reasons. Localized or widespread infections, trauma, burns or acute pancreatitis may be the cause of SIRS (4). The most important source of free oxygen radicals (ROS) for aerobic organisms is molecular oxygen. $98 \%$ of molecular oxygen is normally converted to water by cytochrome oxidase enzyme, while the rest is converted into the reactive toxic products of reduction. ROS also occurs due to enzymatic oxidation of arachidonic acid, as an intermediate product of catalytic cycles of enzymes. We can expect ROS formation due to the oxidation of unsaturated fatty acids or during phagocytosis function of phagocytes (5). In pathological processes such as ischemia and sepsis, the equilibrium between oxidants and antioxidants is disrupted and this results in oxidative stress which reveals the harmful effects of oxidants (6). Oxidative stress is involved in the immune system's response to systemic damage, both with its extracellular effects and as an intracellular signal. In sepsis, ROS plays a key role in the pathogenesis of hemodynamic disorder and organ failure. It induces cytotoxicity in organs and causes changes in cell signal pathways (7).

Hesperidin (Hes), a flavonoid; consists of flavanone hesperitin and disaccharide rutinoz. Hes is the most common flavonoid in orange and lemon (8). It has anti-inflammatory, antioxidant, anti-allergic, hypolipidemic, anti-carcinogenic and vascular protective effects $(9,10)$. Hes has been shown to affect the histamine release and arachidonic acid metabolism (7). The effect of the Hes to destroy free oxygen radicals has been reported in the literature. It also inhibits the effects of pro-inflammatory mediators (11).

Here, we investigated the possible benefical effects of Hes against lung and kidney injuries induced by CLP model which is similar to clinical sepsis with metabolic and hemodynamic properties.

\section{MATERIALS and METHODS}

\section{Animals and Ethical Approval}

Experimental process of the study was performed at Experimental Animals Research and Application Center of Atatürk University. The present study was admitted by Atatürk University Experimental Animal Ethics Committee (Protocol Number:25.01.2018/1). 32 Wistar type Albino male rats weighing 270-280 g, were acquired from the same center. Rats were held in cages with appropriate conditions including humidity of $55 \pm 5 \%$, temperature of $22 \pm 2{ }^{\circ} \mathrm{C}$ under a $12 \mathrm{~h}$ light $/ 12 \mathrm{~h}$ dark cycle. Rats were supplied with standard rat feed and drinking water. All animals were deprived of food 12 hours prior to the experiment, but were allowed to drink water.

\section{Experimental Process, Drugs and Groups}

Rats were fixed in supine position. The abdominal region of the animals were shaved and disinfected via $10 \%$ povidone iodine. The experimental process was performed under anesthesia. Thiopental sodium (50 mg/kg, Ulagay, İstanbul, Turkey) was preferred for the anesthesia (12). Hes solution was prepared in $0.5 \%$ CMC. Hesperidin $(98 \%)$ and sodium carboxymethyl cellulose (CMC) was provided by Sigma-Aldrich Co. USA.

Rats were weighed and classified as 4 groups. The groups were designed as follows;

Sham group $(n=8)$ : In the abdominal midline of the rats, a 1-2 $\mathrm{cm}$ incision was made and closed back. After 16-18 hours (sepsis time), tissues of lungs and kidneys were excised.

CLP group $(n=8)$ : Following the same incision in sham group, the abdominal muscles and peritoneum were crossed and the cecum was removed. It was tied with a 4.0 suture with a size of $2 \mathrm{~cm}$ at the distal part of cecum. In addition, 4 holes were drilled from this distal cecum region with the help of an 18 gauge needle. Afterwards, the cecum and intestine sections were placed back into abdomen. $2 \mathrm{ml}$ of saline was emptied into the abdomen and the incision line was sutured. CLP method was selected with the reference of a previous experimental study (13).

Hes $100 \mathrm{mg} / \mathrm{kg}$ group ( $\mathrm{n}=8): 100 \mathrm{mg} / \mathrm{kg}$ Hes was adminis- 
Hesperidin Alleviates Cecal Ligation and Puncture-Induced Lung and Kidney Injuries

tered once a day for 15 days by oral gavage. After the application of last dose of Hes, CLP induction was carried out as described in group II.

Hes $200 \mathrm{mg} / \mathrm{kg}$ group ( $\mathrm{n}=8$ ): $200 \mathrm{mg} / \mathrm{kg}$ of Hes was administered once daily for 15 days with oral gavage and all procedures in the group II were repeated.

After 16-18 hours, these rats were sacrificed, the lung and kidney tissues were collected.

\section{Biochemical Measurements}

Tissue samples, each weighing $100 \mathrm{mg}$, were homogenized by $2 \mathrm{~mL}$ of phosphate buffer solution (PBS) and centrifuged at $5000 \mathrm{rpm}$ at $+4{ }^{\circ} \mathrm{C}$ for 20 minutes. The supernatants were kept at $-80^{\circ} \mathrm{C}$ in eppendorf tubes. The values of total oxidant status (TOS) and total antioxidant status (TAS) were determined using ELISA kits (Rel Assay Diagnostics). The rate of TOS to TAS was accepted as oxidative stress index (OSI). The measurement of malondialdehyde (MDA) (14), myeloperoxidase (MPO) (15) and superoxide dismutase (SOD) (16) levels were carried out as described in previous studies.

\section{Immunohistochemical (IHC) Staining}

After the kidney and lung tissues were held in neutral formaldehyde solution for 24 hours, formaldehyde was removed by washing with tap water. Tissues were routinely blocked through alcohol-xylol and blocked in paraffin. Following the tissue deparaffinization, they were taken on the polylysine coated slide and left for 10 minutes in 3\% H2O2 and washed in phosphate buffered solution (PBS) to passivate the activity of endogenous peroxidase. Then, they were held in antigen retrieval solution at $500 \mathrm{w}$ for 10 minutes and washed in PBS to reveal antigens in the tissues. To prevent nonspecific binding, protein block solution was added and washed in PBS. Light chain 3 (LC3B) (Abcam, Cat. No: ab48394 Dilution: 1/200) and cleaved caspase-3 (Novus Biological, Cat. No: NB600-1235, Dilution: 1/100) were applied as primary antibody to PBS-washed sections. After all, the procedure specified by Expose mouse and rabbit specific HRP/DAB detection IHC kit (Abcam: ab80436) was performed. 3.3 'diaminobenzidine chromogen was used and hematoxylin was preferred for contrast staining. Positive cells were investigated under a light microscope at $20 \mathrm{x}$ magnification.

\section{Statistical Analyses}

Firstly, one-way ANOVA test was chosen for biochemical data and then Tukey HSD test was preferred for multiple comparisons. The results were given as Mean \pm Standard Deviation (SD). A p value below 0.05 was considered statistically significan.

\section{RESULTS}

\section{Lung Tissue Biochemical Results}

The changes in TAS, TOS, OSI parameters were demonstrated in Table I. SOD, MPO, MDA levels were presented in Figure 1. TAS level decreased in CLP group compared to sham group and increased in both Hes treatment groups compared to CLP group $(\mathrm{p}<0.05)$. TOS, MPO, MDA and OSI levels were elevated in CLP group compared to sham group and diminished in both Hes treatment groups compared to CLP group $(p<0.05)$. SOD enzyme levels did not differ among the groups $(\mathrm{p}>0.05)$.

Table I: Effects of Hes treatment on biochemical parameters in CLP-induced lung injury.

\begin{tabular}{lccc}
\hline $\begin{array}{l}\text { Experimental } \\
\text { Groups }(\mathbf{n}=\mathbf{8})\end{array}$ & $\begin{array}{c}\text { TAS } \\
(\mathbf{m m o l} / \mathbf{L})\end{array}$ & $\begin{array}{c}\text { TOS } \\
(\boldsymbol{\mu m o l} / \mathbf{L})\end{array}$ & $\begin{array}{c}\text { OSI } \\
(\text { arbitrary unit) }\end{array}$ \\
\hline Sham & $0.79 \pm 0.14$ & $8.75 \pm 1.00$ & $1.11 \pm 0.18$ \\
CLP & $0.23 \pm 0.09^{\mathrm{a}}$ & $10.36 \pm 0.81^{\mathrm{a}}$ & $5.22 \pm 2.15^{\mathrm{a}}$ \\
$\mathrm{Hes} 100 \mathrm{mg} / \mathrm{kg}$ & $0.65 \pm 0.20^{\mathrm{b}}$ & $8.50 \pm 0.85^{\mathrm{b}}$ & $1.42 \pm 0.47^{\mathrm{b}}$ \\
$\mathrm{Hes} 200 \mathrm{mg} / \mathrm{kg}$ & $0.73 \pm 0.08^{\mathrm{b}}$ & $8.41 \pm 0.37^{\mathrm{b}}$ & $1.04 \pm 0.42^{\mathrm{b}}$ \\
\hline${ }^{\mathrm{a}} \mathrm{p}<0.05$ compared to &
\end{tabular}
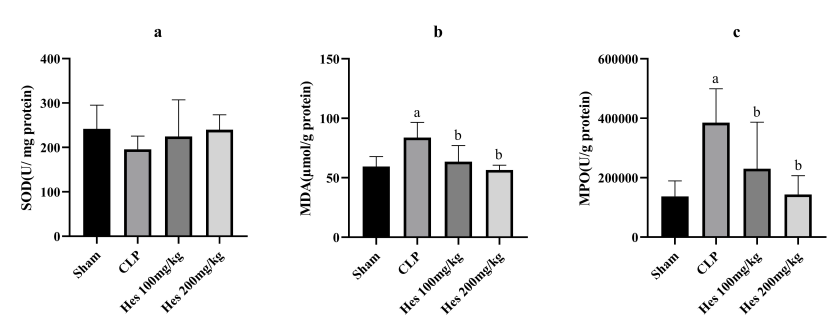

Figure 1: Effect of Hes on the levels of (a) SOD, (b) MDA and (c) MPO in CLP-stimulated lung tissues. ap $<0.05$ compared to sham group and $b p<0.05$ compared to CLP group. Data were expressed as Mean $\pm \mathrm{SD}$.

\section{Kidney Tissue Biochemical Results}

The changes in TAS, TOS and OSI parameters (Table II) and SOD, MPO and MDA parameters (Figure 2) were presented. No significant difference among the groups was detectedfor the TAS levels $(p>0.05)$. TOS, OSI and MDA levels raised in CLP group compared to sham group and declined in HES treatment groups compared to CLP group $(\mathrm{p}<0.05)$. SOD enzyme levels decreased in CLP group compared to sham group $(p<0.05)$. SOD level increased in high dose Hes treatment group compared to CLP group $(p<0.05)$. MPO activity did not display any difference among the groups $(\mathrm{p}>0.05)$.

Table II: Effects of Hes treatment on biochemical parameters in CLP-induced kidney injury.

\begin{tabular}{lccc}
\hline $\begin{array}{l}\text { Experimental } \\
\text { Groups }(\mathbf{n}=\mathbf{8})\end{array}$ & $\begin{array}{c}\text { TAS } \\
(\mathbf{m m o l} / \mathbf{L})\end{array}$ & $\begin{array}{c}\text { TOS } \\
(\boldsymbol{\mu m o l} / \mathbf{L})\end{array}$ & $\begin{array}{c}\text { OSI } \\
(\text { arbitrary unit) }\end{array}$ \\
\hline Sham & $1.67 \pm 0.38$ & $6.80 \pm 0.96$ & $0.42 \pm 0.10$ \\
CLP & $1.35 \pm 0.28$ & $8.35 \pm 0.57^{\mathrm{a}}$ & $0.65 \pm 0.18^{\mathrm{a}}$ \\
$\mathrm{Hes} 100 \mathrm{mg} / \mathrm{kg}$ & $1.63 \pm 0.22$ & $7.10 \pm 0.94^{\mathrm{b}}$ & $0.44 \pm 0.10^{\mathrm{b}}$ \\
$\mathrm{Hes} 200 \mathrm{mg} / \mathrm{kg}$ & $1.57 \pm 0.26$ & $6.74 \pm 0.73^{\mathrm{b}}$ & $0.41 \pm 0.05^{\mathrm{b}}$ \\
\hline${ }^{\mathrm{a}} \mathrm{p}<0.05$ compared to sham group. ${ }^{\mathrm{b}} \mathrm{p}<0.05$ compared to CLP group.
\end{tabular}




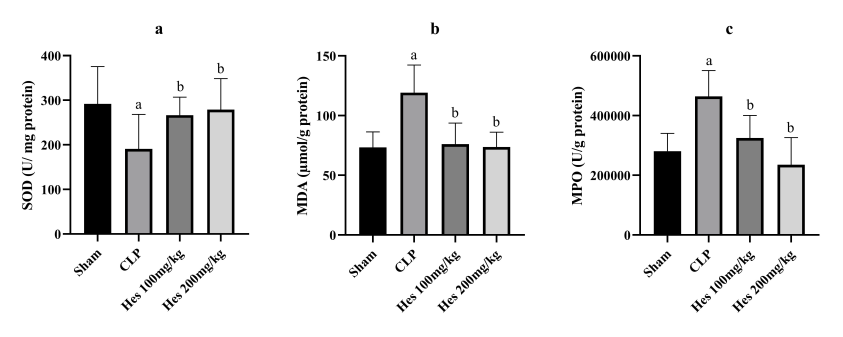

Figure 2: Effect of Hes on the levels of (a) SOD, (b) MDA and (c) MPO in CLP-stimulated kidney tissues. ap $<0.05$ compared to sham group and $\mathrm{bp}<0.05$ compared to CLP group. Data were expressed as Mean \pm SD.

\section{IHC Results}

Caspase-3 and LC3B IHC staining in lung tissues were presented in figure 3. For the lung tissues, there was no caspase-3 immunopositivity in sham group while it was intense in CLP group. A decrease in caspase-3 immunopositivity was observed in Hes $100 \mathrm{mg} / \mathrm{kg}$ dose group. In Hes 200 $\mathrm{mg} / \mathrm{kg}$ dose group, caspase-3 immunopositivity was found quite mildly. There was no immunopositivity in sham group for the LC3B staining. In Hes $100 \mathrm{mg} / \mathrm{kg}$ dose group, a decrease in LC3B immunopositivity was observed and it was quite mild in Hes $200 \mathrm{mg} / \mathrm{kg}$ dose group.

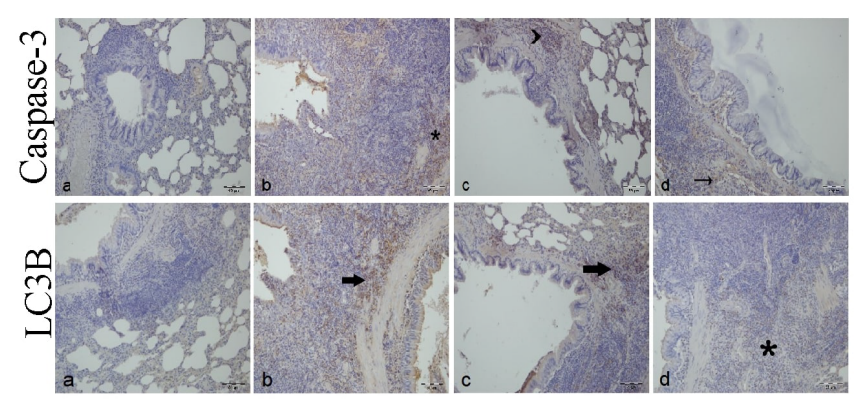

Figure 3: Presentation of Caspase-3 and LC3B IHC staining in lung tissues a) Sham group b) CLP group, intense immunopositivity in BALT (star or arrow) c) Hes $100 \mathrm{mg} / \mathrm{kg}$, moderate immunopositivity in BALT (arrow or arrow head) d) Hes $200 \mathrm{mg} / \mathrm{kg}$ group, mild immunopositivity in BALT (star or arrow).

Caspase-3 and LC3B IHC staining in kidney tissues are presented in Figure 4. Caspase-3 immunopositivity was not seen in sham group. It was observed intensively in tubules and glomerulus samples of CLP group. In Hes $100 \mathrm{mg} / \mathrm{kg}$ dose group, caspase-3 immunopositivity was at medium severity in tubules and it was mildly present in tubules of Hes $200 \mathrm{mg} / \mathrm{kg}$ dose group. There was no immunopositivity in sham group for the LC3B staining. On the other side, LC3B immunopositivity was intense in both CLP and Hes 100 $\mathrm{mg} / \mathrm{kg}$ dose groups. In Hes $200 \mathrm{mg} / \mathrm{kg}$ dose group, a decrease in LC3B immunopositivity was observed.

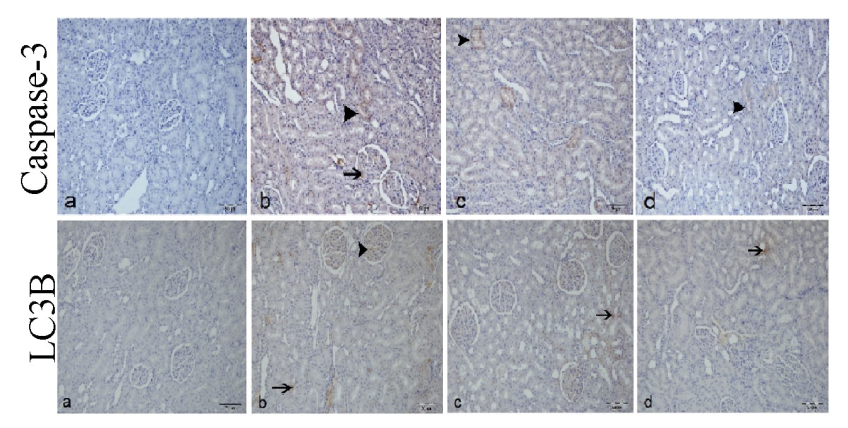

Figure 4: Presentation of Caspase-3 and LC3B IHC staining in kidney tissues a) Sham group b) CLP group, glomerulus (arrow) and tubules (arrow head)display intense immunopositivity c) Hes $100 \mathrm{mg} / \mathrm{kg}$, moderate immunopositivity in tubules (arrow head) d) Hes $200 \mathrm{mg} / \mathrm{kg}$ group; mild immunopositivity in tubules (arrow head).

\section{DISGUSSION}

Sepsis is the widespread inflammatory response which can occur in both primary focus of infection and remote organs (17). It is characterized by infection and inflammation which causes mortality (18). Surviving ratio of septic patients increases with care (19). Sepsis is an important and extensive clinical condition demonstrating morbidity and mortality. $20-30 \%$ of one million sepsis cases results in death in North America annually. Sepsis is the most common death cause in hospitalized patients (20-22). It mostly results from bacterial infections. It causes end organ failure. Infection induces SIRS which causes multiple organ failure and immunological abnormalities $(23,24)$. CLP model has been used to be able to solve the mechanisms of sepsis $(25,26)$. It is widely used among the many murine models of sepsis $(27,28)$. In CLP experimental model, intestinal flora is used to form peritonitis and this resembles bowel perforation. Sepsis duration and range of bacterial flora are quite similar with clinical sepsis cases $(29,30)$.

Free radicals emerge as the natural product of physiological activity in the body and they are balanced by the oxidant-antioxidant mechanisms. In cases where excessive production of free radicals occurs or antioxidant defense mechanisms remain incapable, oxidative stress occurs. Due to oxidative stress, cell damage can occur as a result of free radicals reacting with cell membrane lipids, DNA, carbohydrates and proteins (31). Antioxidants reduce the damage caused by radicals, suppress radical formation mechanisms, neutralize the produced radicals, stop chain reactions that cause radical production including lipid peroxidation and ultimately provide cell defense (32). Even though several studies have been performed $(13,33-35)$, the pathophysiology of sepsis in humans remains unclear $(36,37)$. Clinical and experimental studies support the benefits of antioxidants against sepsis including lung injury as remote organ $(38,39)$. Antioxidants may alleviate sepsis related inflammation and tissue injury by means of free radical scavenging and enhancing antioxidant 
defense system $(40,41)$.

Free radicals lead to lipid peroxidation which reduces membrane potential and results in cell injury. MDA is a lipid peroxidation product and also causes serious cell damage (42). Therefore, ROS and MDA are considered as biomarkers for the detection of oxidative stress (43). Elevation was observed in MDA levels after lipid peroxidation in CLP-induced rat sepsis models $(44,45)$. MPO enzyme is considered as an indicator for neutrophil infiltration (46). During inflammation, neutrophils release excessive amounts of MPO (47). SOD is the primary antioxidant associated with scavenging free radicals (48).

High levels of ROS in the cells lead to the stimulation of the apoptosis, while the low levels act as a signaling molecule that regulates cell growth and survival (49). When the ROS production is inducted, it results in pro-apoptotic gene upregulation, caspase activation and apoptotic cell death (50). The caspases are triggered by signals that activate apoptosis and actively take part in apoptosis pathways (51). Caspase 3, 6 and 7 are responsible for breaking down of cells (52). In previous studies using an experimental sepsis model, it was found that especially MDA levels increased significantly in sepsis, but the antioxidant defense was insufficient (44, 45, 53). The results of the present study are consistent with the findings of previous studies.

Autophagy involves autophagosome formation that ingests dysfunctional or damaged organelles and proteins. Actually, autophagy is necessary for development and differentiation as well as cellular maintenance (54-56). Although autophagy maintains cellular homeostasis, it also can be protective or harmful due to the conditions (57). LC3B is a cellular indicator of autophagy (58). In the beginning of autophagy, phagophore occurs. Phagophore is a sort of membrane where LC3-I and lipids are attached $(59,60)$. LC3-II accumulation is evaluated as a marker of damaged autophagy (61). In a CLP-induced experimental sepsis model, the level of LC3-II in the heart tissues were significantly increased $(62,63)$. In accordance with the results of previous studies, current study shows that LC3B immunopositivity is intense in CLP and decreases with Hes administration.

\section{CONGLUSION}

In this study, it has been shown that treatment with Hes reduces lung and kidney injuries in experimental animals exposed to CLP-induced sepsis model. Further studies would be helpful to explain the possible protective mechanisms in lung and kidney injuries induced by sepsis.

\section{Conflict of interest}

None.

\section{Data availability statement}

None.

\section{Ethics Committee Approval}

The present study was admitted by Atatürk University Experimental Animal Ethics Committee (Protocol Number:25.01.2018/1).

\section{Financial Disclosure}

No support was received from any institution in the realization of this study. The necessary resources for the study were provided by the authors. There is no financial conflict between the authors.

\section{Author Contributions}

Güzel Erdoğan D, Tanyeli A, Ekinci Akdemir FN, Güler MC, and Eraslan E contributed in the planning of design and animal experimental process, literature review, critical language revision and writing of this study. Çomakli S performed histopathological and immunohistochemical evaluations. Polat E carried out the biochemical measurements and statistical analyses. 


\section{REFERENGES}

1. Lever A, Mackenzie I. Sepsis: definition, epidemiology, and diagnosis. Bmj 2007; 335(7625): 879-83.

2. Russell JA. Management of sepsis. New Eng J Med 2006; 355(16):1699-713.

3. Babayigit H, Kucuk C, Sozuer E, Yazici C, Kose K, Akgun H. Protective effect of beta-glucan on lung injury after cecal ligation and puncture in rats. Intensive Care Med 2005; 31(6): 865-70.

4. Klosterhalfen B, Bhardwaj R. Septic shock. General Pharmacology: The Vascular System 1998; 31(1): 25-32.

5. Chang B, Nishikawa M, Sato E, Utsumi K, Inoue M. L-Carnitine inhibits cisplatin-induced injury of the kidney and small intestine. Arch Biochem Biophys 2002; 405(1): 55-64.

6. Kaymak C, Basar H, Sardas S. Reactive oxygen species (ROS) generation in sepsis. FABAD J Pharm Sci 2011; 36(1): 41-7.

7. De Jong HK, Van Der Poll T, Wiersinga WJ. The systemic pro-inflammatory response in sepsis. J Innate Immun 2010; 2(5): 422-30.

8. Garg A, Garg S, Zaneveld L, Singla A. Chemistry and pharmacology of the citrus bioflavonoid hesperidin. Phytother Res 2001; 15(8): 655-69.

9. Ekinci Akdemir FN, Gulcin I, Karagoz B, Soslu R, Alwasel SH. A comparative study on the antioxidant effects of hesperidin and ellagic acid against skeletal muscle ischemia/reperfusion injury. J Enzyme Inhib Med Chem 2016; 31(4): 114-8.

10. Garg A, Garg S, Zaneveld LJ, Singla AK. Chemistry and pharmacology of the Citrus bioflavonoid hesperidin. Phytother Res 2001; 15(8): 655-69.

11. Jin MJ, Kim U, Kim IS, Kim Y, Kim D-H, Han SB, Kim $\mathrm{DH}$, Kwon OS, Yoo HH. Effects of gut microflora on pharmacokinetics of hesperidin: a study on non-antibiotic and pseudo-germ-free rats. J Toxicol Environ Health, Part A. 2010; 73(21-22): 1441-50.

12. Tanyeli A, Ekinci Akdemir FN, Eraslan E, Guler MC, Nacar T. Anti-oxidant and anti-inflamatuar effectiveness of caftaric acid on gastric ulcer induced by indomethacin in rats. Gen Physiol Biophys 2019; 38(2): 175-81.

13. Ekinci Akdemir FN, Tanyeli A. The Antioxidant Effect of Fraxin against Acute Organ Damage in Polymicrobial Sepsis Model induced Cecal Ligation and Puncture. Turk J Sci 2019; 4(1): 22-9.
14. Ohkawa H, Ohishi N, Yagi K. Assay for Lipid Peroxides in Animal-Tissues by Thiobarbituric Acid Reaction. Anal Biochem 1979; 95(2): 351-8.

15. Bradley PP, Priebat DA, Christensen RD, Rothstein G. Measurement of cutaneous inflammation: estimation of neutrophil content with an enzyme marker. J Invest Dermatol 1982; 78(3): 206-9.

16. Sun Y, Oberley LW, Li Y. A Simple Method for Clinical Assay of Superoxide-Dismutase. Clin Chem 1988; 34(3): 497-500.

17. Neviere RR, Cepinskas G, Madorin WS, Hoque N, Karmazyn M, Sibbald WJ, Kvietys PR. LPS pretreatment ameliorates peritonitis-induced myocardial inflammation and dysfunction: role of myocytes. Am J Physiol 1999; 277(3): 885-92.

18. Liu V, Escobar GJ, Greene JD, Soule J, Whippy A, Angus DC, Iwashyna TJ. Hospital deaths in patients with sepsis from 2 independent cohorts. Jama 2014; 312(1): 90-2.

19. Kaukonen KM, Bailey M, Suzuki S, Pilcher D, Bellomo R. Mortality related to severe sepsis and septic shock among critically ill patients in Australia and New Zealand, 2000-2012. Jama 2014; 311(13): 1308-16.

20. Ferrer R, Artigas A, Suarez D, Palencia E, Levy MM, Arenzana A, Pérez, XL, Sirvent JM, Group ES. Effectiveness of treatments for severe sepsis: a prospective, multicenter, observational study. Am J Res Critical Care Med 2009; 180(9): 861-6.

21. Husak L, Marcuzzi A, Herring J, Wen E, Yin L, Capan DD, Cernat G. National analysis of sepsis hospitalizations and factors contributing to sepsis in-hospital mortality in Canada. Healthcare quarterly (Toronto, Ont) 2010; 13: 35-41.

22. Angus DC, van der Poll T. Severe sepsis and septic shock. New Eng J Med 2013; 369(21): 2063.

23. Levy MM, Fink MP, Marshall JC, Abraham E, Angus D, Cook D, Cohen J, Opal SM, Vincent JL, Ramsay G. $2001 \mathrm{SCCM} / \mathrm{ESICM} / \mathrm{ACCP} / \mathrm{ATS} / \mathrm{SIS}$ International Sepsis Definitions Conference. Critical Care Med 2003; 31(4): 1250-6.

24. Munford RS. Severe sepsis and septic shock: the role of gram-negative bacteremia. Annu Rev Pathol 2006; 1: 467-96.

25. Remick DG, Newcomb DE, Bolgos GL, Call DR. Comparison of the mortality and inflammatory response of two models of sepsis: lipopolysaccharide vs. cecal 
ligation and puncture. Shock (Augusta, Ga) 2000; 13(2): 110-6.

26. Wichterman KA, Baue AE, Chaudry IH. Sepsis and septic shock--a review of laboratory models and a proposal. J Surg Res 1980; 29(2): 189-201.

27. Howell GM, Gomez H, Collage RD, Loughran P, Zhang X, Escobar DA, Billiar TR, Zuckerbraun BS, Rosengart MR. Augmenting autophagy to treat acute kidney injury during endotoxemia in mice. PloS one 2013; 8(7): 69520.

28. Zhang X, Guo L, Collage RD, Stripay JL, Tsung A, Lee JS, Rosengart MR. Calcium/calmodulin-dependent protein kinase (CaMK) Ialpha mediates the macrophage inflammatory response to sepsis. J Leukoc Biol 2011; 90(2): 249-61.

29. Macdonald J, Galley HF, Webster NR. Oxidative stress and gene expression in sepsis. Brit $\mathrm{J}$ Anaesth 2003;90(2):221-32.

30. Poli-de-Figueiredo LF, Garrido AG, Nakagawa N, Sannomiya P. Experimental models of sepsis and their clinical relevance. Shock (Augusta, Ga) 2008; 38(1): 53-9.

31. Sorg O. Oxidative stress: a theoretical model or a biological reality? C R Biol 2004; 327(7): 649-62.

32. McCord JM. The evolution of free radicals and oxidative stress. Am J Med 2000; 108(8): 652-9.

33. Quoilin C, Mouithys-Mickalad A, Lecart S, Fontaine-Aupart MP, Hoebeke M. Evidence of oxidative stress and mitochondrial respiratory chain dysfunction in an in vitro model of sepsis-induced kidney injury. Biochimic Biophys Acta 2014; 1837(10): 1790-800.

34. Lowes DA, Webster NR, Murphy MP, Galley HF. Antioxidants that protect mitochondria reduce interleukin-6 and oxidative stress, improve mitochondrial function, and reduce biochemical markers of organ dysfunction in a rat model of acute sepsis. Brit $\mathbf{J}$ Anaesth 2013; 110(3): 472-80.

35. Galley HF. Oxidative stress and mitochondrial dysfunction in sepsis. Brit J Anaesth 2011; 107(1): 57-64.

36. Sagy M, Al-Qaqaa Y, Kim P. Definitions and pathophysiology of sepsis. Curr Prob Pediatr AD 2013; 43(10): 260-3.

37. Gotts JE, Matthay MA. Sepsis: pathophysiology and clinical management. BMJ (Clinical research ed) 2016; 353: 1585 .
38. Chu SJ, Chang DM, Wang D, Hsu K, Chiang CH. Protective effect of lipophilic antioxidants on phorbol-induced acute lung injury in rats. Critical Care Med 2001; 29(4): 819-24.

39. Ortolani O, Conti A, De Gaudio AR, Masoni M, Novelli $\mathrm{G}$. Protective effects of $\mathrm{N}$-acetylcysteine and rutin on the lipid peroxidation of the lung epithelium during the adult respiratory distress syndrome. Shock (Augusta, Ga) 2000; 13(1): 14-8.

40. Ritter C, Andrades ME, Reinke A, Menna-Barreto S, Moreira JC, Dal-Pizzol F. Treatment with N-acetylcysteine plus deferoxamine protects rats against oxidative stress and improves survival in sepsis. Critical Care Med 2004; 32(2): 342-9.

41. Zolali E, Hamishehkar H, Maleki-Dizaji N, Majidi Zolbanin N, Ghavimi H, Kouhsoltani M, Asgharian P. Selenium effect on oxidative stress factors in septic rats. Adv Pharm Bull 2014; 4(3): 289-93.

42. Girotti AW. Lipid hydroperoxide generation, turnover, and effector action in biological systems. J Lipid Res 1998; 39(8): 1529-42.

43. Topdağı Ö, Tanyeli A, Ekinci Akdemir FN, Eraslan E, Güler MC. Barbaloin Attenuates Oxidative Testicular Injury Induced by Ischemia Reperfusion via Antioxidant Effects. Turk J Sci 2020; 5(1): 28-33.

44. Toklu HZ, Tunali Akbay T, Velioglu-Ogunc A, Ercan F, Gedik N, Keyer-Uysal M, Sener G. Silymarin, the antioxidant component of Silybum marianum, prevents sepsis-induced acute lung and brain injury. J Surg Res 2008; 145(2): 214-22.

45. Koksal GM, Sayilgan C, Aydin S, Oz H, Uzun H. Correlation of plasma and tissue oxidative stresses in intra-abdominal sepsis. J Surg Res 2004; 122(2): 180-3.

46. Funakoshi T, Ishibe Y, Okazaki N, Miura K, Liu R, Nagai $\mathrm{S}$, Minami Y. Effect of re-expansion after short-period lung collapse on pulmonary capillary permeability and pro-inflammatory cytokine gene expression in isolated rabbit lungs. Brit J Anaesth 2004; 92(4): 558-63.

47. Gaut JP, Yeh GC, Tran HD, Byun J, Henderson JP, Richter GM, Brennan ML, Lusis AJ, Belaaouaj A, Hotchkiss RS, Heinecke JW. Neutrophils employ the myeloperoxidase system to generate antimicrobial brominating and chlorinating oxidants during sepsis. PNAS USA 2001; 98(21): 11961-6. 
48. Tanyeli A, Güzel Erdoğan D, Ekinci Akdemir FN, Eraslan E and Güler MC. The Role of Chlorogenic Acid in Alleviating Intestinal Ischemia/Reperfusion-Induced Lung Injury, New Trend Med Sci 2020; 1(2): 59-64.

49. Kroemer G, Mariño G, Levine B. Autophagy and the integrated stress response. Mol Cell 2010; 40(2): 280-93.

50. Tuncer AA, Bozkurt MF, Koken T, Dogan N, Pektas MK, Baskin Embleton D. The Protective Effects of Alpha-Lipoic Acid and Coenzyme Q10 Combination on Ovarian Ischemia-Reperfusion Injury: An Experimental Study. Adv Med 2016; 2016: 3415046.

51. Hengartner MO. The biochemistry of apoptosis. Nature 2000; 407(6805): 770

52. Kaufmann SH, Earnshaw WC. Induction of apoptosis by cancer chemotherapy. Exp Cell Res 2000; 256(1): 42-9.

53. Eraslan E, Tanyeli A, Güler MC, Ekinci-Akdemir FN, Nacar T, Topdağı Ö, Polat E. Nrf2 inhibitor brusatol ameliorates cecal ligation and puncture-induced lung injury in rats via anti-inflammation and anti-oxidative stress. Turk Hij Den Biyol Derg 2020; 77(4): 467-476.

54. Almasaudi SB, Abbas AT, Al-Hindi RR, El-Shitany NA, Abdel-Dayem UA, Ali SS, Saleh RM, Al Jaouni SR, Kamal MA, Harakeh SM. Manuka Honey Exerts Antioxidant and Anti-Inflammatory Activities That Promote Healing of Acetic Acid-Induced Gastric Ulcer in Rats. Evid Based Complement Alternat Med 2017; 2017: 5413917.
55. Tanida I, Ueno T, Kominami E. LC3 conjugation system in mammalian autophagy. Int J Biochem Cell Biol 2004; 36(12): 2503-18.

56. Qu L, Chen C, Chen Y, Li Y, Tang F, Huang H, He W, Zhang R, Shen L. High-Mobility Group Box 1 (HMGB1) and Autophagy in Acute Lung Injury (ALI): A Review. Med Sci Monit 2019; 25: 1828-37.

57. Wang K, Chen Y, Zhang P, Lin P, Xie N, Wu M. Protective Features of Autophagy in Pulmonary Infection and Inflammatory Diseases. Cells 2019; 8(2).

58. Klionsky DJ, Abeliovich H, Agostinis P, Agrawal DK, Aliev G, Askew DS, et al. Guidelines for the use and interpretation of assays for monitoring autophagy in higher eukaryotes. Autophagy 2008; 4(2): 151-75.

59. Barth S, Glick D, Macleod KF. Autophagy: assays and artifacts. J Pathol 2010;221(2):117-24.

60. Glick D, Barth S, Macleod KF. Autophagy: cellular and molecular mechanisms. J Pathol 2010; 221(1): 3-12.

61. Wu XJ, Yan XT, Yang XM, Zhang Y, Wang HY, Luo H, et al. GTS-21 ameliorates polymicrobial sepsis-induced hepatic injury by modulating autophagy through alpha7nAchRs in mice. Cytokine 2020; 128: 155019.

62. Hsieh CH, Pai PY, Hsueh HW, Yuan SS, Hsieh YC. Complete induction of autophagy is essential for cardioprotection in sepsis. Ann Surg 2011; 253(6): 1190-200.

63. Moulis M, Vindis C. Methods for Measuring Autophagy in Mice. Cells 2017 ;6(2). 